MARKETING AND BRANDING
RESEARCH $\begin{gathered}\text { INDUSTRIAL } \\ \text { MANAGEMENT } \\ \text { INSTITUTE }\end{gathered}$

\title{
Measuring the effect of perceived logistics service quality on brand factors in the e-commerce context
}

\author{
Ebru SÜRÜCÜ*, Nergis ÖZİSPA \\ Research Assistant, Department of Maritime Business Administration, Faculty of Maritime, Dokuz Eylul \\ University, Izmir, Turkey
}

\begin{abstract}
Keywords:

Brand Loyalty, Brand

Trust, E-Commerce,

Logistics Service

Quality, Perceived

Quality

Correspondence:

ebru.surucu@deu.edu.

$\operatorname{tr}$

In e-commerce industry while most of the transactions happen electronically, logistics activities are still required to ship products to end points. Firms that operate in e-commerce industry should consider logistics as a critical success factor if they want to be successful in operations. Studies show that customers choose strong brands in e-commerce to get better logistics service. Main purpose of this research is to examine the consequences of logistics service quality on brand factors considering e-commerce industry. To this end, for brand factors including quality (PQ), brand loyalty (BL), and brand trust (BT), and logistics service quality (LSQ), a literature review is made. According to this literature review, a survey is prepared and sent to e-commerce website users via email and online survey software. The originality of this study lies on the investigation of how perceived logistics service quality affects perceived quality, brand trust, and brand loyalty from the e-commerce perspective for the first time. As an exploratory study that links logistics service quality with brand, the study investigates how logistics service quality characteristics, namely timelines, order condition, information quality, personal contact quality, ordering procedures, ordering release quantities, order accuracy, order quality, and order discrepancy handling affect brand factors as perceived quality, brand loyalty, and brand trust. To that end, the data collected based on responses from 193 online shopping website users. Based on the factor analysis results, 6 groups are identified for LSQ. The results indicated that logistics service quality has an impact on perceived quality and brand trust and it has no impact on brand loyalty. At the end, implications of these findings for managers and directions for future research are presented.
\end{abstract}

(C)AIMI Journals

Delivering the finished goods to consumers is a critical activity in any business. Moreover, it is crucially important to identify customer-related activities such as order receiving, sales and marketing, 
and processing, and shipment of the ordered goods (Mentzer \& Williams, 2001). Digital technology has enabled a new paradigm and changed our lives with the interaction of Internet (Huang, Kuo, \& $\mathrm{Xu}, 2009$ ) because of its convenient and interactive nature, lower costs, high degree of customization, and personalization to customers (Park \& Baek, 2007). Electronic commerce (e-commerce) brings huge business opportunities like product sales, online service provision, and revenue for growth (Rohm \& Swaminathan, 2004).

The quality of logistics service is an important key marketing concept that helps to create brand value (Mentzer, Flint, \& Hult, 2001). However, many studies on logistics service quality have focused on exploring the relationship between logistics service quality, customer satisfaction, and customer loyalty (Lin, Luo, Cai, Ma, \& Rong, 2016).

Based on these ideas, the purpose of this research is twofold. First, it contributes to the logistics service quality with a conceptualization and measurement of brand concept. According to this aim, the present study develops the conceptual model which is proposed in Figure 1. Second, LSQ scale is used within a different customer segment which is e-commerce industry, other than construction, electronics, fuel, industrial supplies, and medical supplies (Jaafar \& Rafiq, 2005). To address these purposes, the rest of this paper is organized as follows. Logistics service quality and brand factors' literature is reviewed in the following section. This study focuses on unnoted techniques of theory elaboration (Lee, 1999) which includes employing and boosting theory into new settings or context. According to this technique, expected theoretical model and main hypotheses of this study are presented. Subsequently, the data collection, the method used to test the hypotheses and the results are described. Finally, we discuss the results in terms of their implications for managerial practice, and their limitations and directions for further research on the LSQ and branding literature. Figure 1 presents the conceptual model of research.

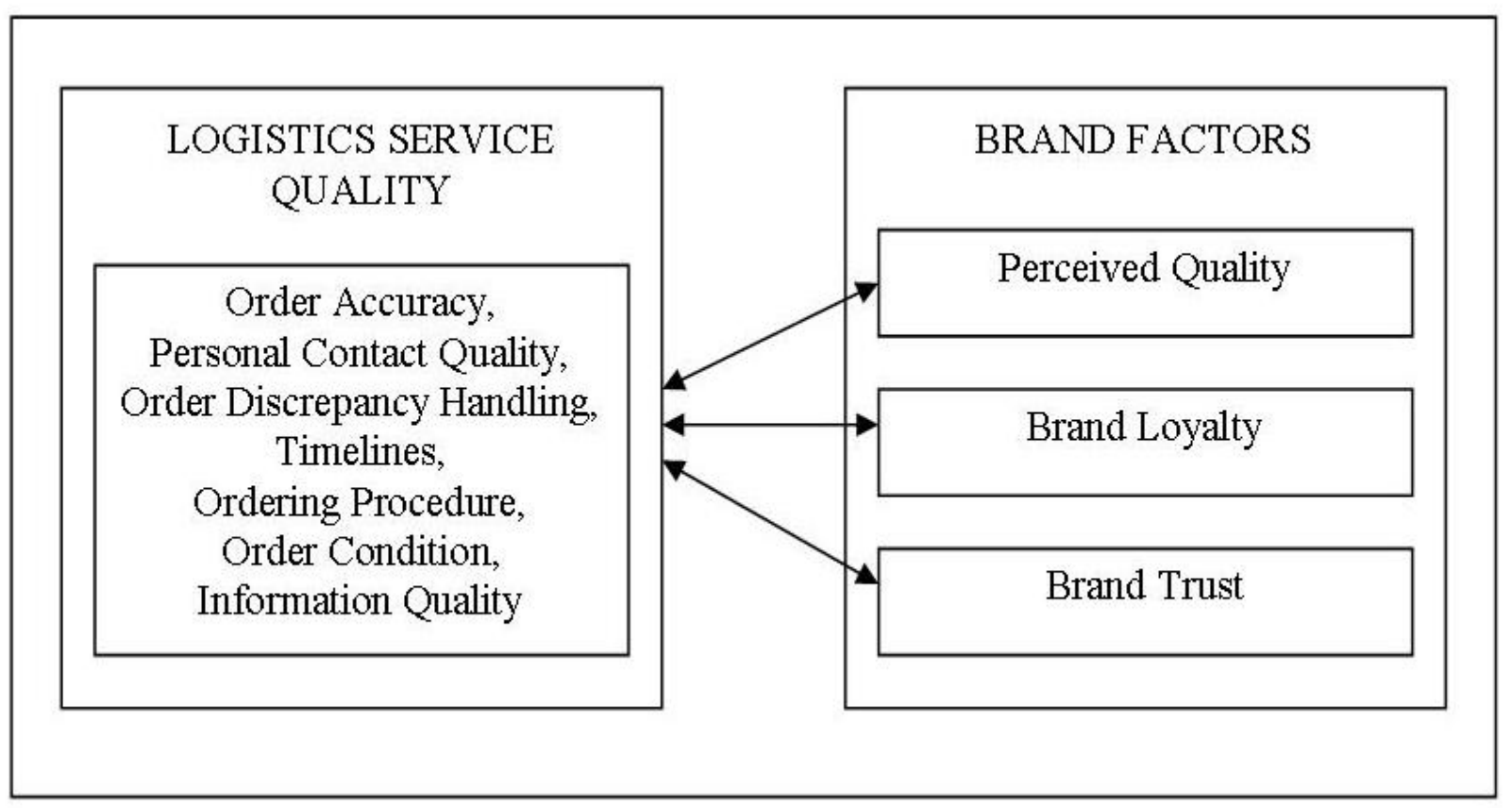

Figure 1. Conceptual model

Theoretical Foundation

Insights from Perceived Quality, Brand Loyalty, and Brand Trust Literature 
Perceived quality is a component of brand value. Zeithaml (1998) defines perceived quality as a consumer's feeling of a product's supremacy. It is a competitive necessity and companies have turned it into a strategic weapon (Atilgan, Aksoy, \& Akinci, 2005). Consumers' judgment about quality can be influenced by personal product experiences, personal needs, and consumption condition. Consumer notices brand's supremacy when he/she feels high-perceived quality through a long-term product usage (Yoo, Donthu, \& Lee, 2000). Thus, consumer would prefer to buy product which gives highperceived quality compared to other brands (Zeithaml, 1998). Perceived quality is valuable in several ways. In many situations, perceived quality of a brand is the main reason to buy. Moreover, it enables to charge a premium price (Tuominen, 1999).

Brand loyalty is defined as a situation which reflects on what possibility a customer will alter using brand with a different brand, specifically when brand changes product's price or features (Aaker, 1991). Nonetheless, according to Keller (2003), brand loyalty defined under the "brand resonance" term, which refers to the nature of customer-brand relationship and the feeling of customers about how they are "in sync" with the brand. A high degree of loyalty will be achieved when customers have a resonance with brand. Moreover, they constantly find new ways to interact with the brand and share their experiences with others. Purchasing a brand regularly and refusing changing the brand are some of the outcomes of brand loyalty (Yoo et. al., 2000). However, it is challenging to build and support brand loyalty due to the fact that there are plenty of brands on the market targeting the same consumers who come across several alternatives that have more advantageous (Wood, 2004). In an extensive definition, brand loyalty is described by six sufficient conditions considering that brand loyalty is prejudiced response, it is a behavioral response, it is stated over time, some decision-making unit makes brand loyalty, it is created with regarding one or more alternative brands within similar brands, and it is a function of psychological process (Jacoby \& Kyner, 1973).

In the marketing literature, there are two dimensions for measuring brand loyalty. First dimension is the behavioral loyalty meaning consistent purchasing of one brand over time as an indication of brand loyalty. Behavioral definitions of brand loyalty represent repeated purchasing of a brand (Yang \& Peterson, 2004; Kim, Jin-Sun, \& Kim., 2008); however, alone it is not enough to explain how various buying situations aggravate buying the same brand by consumer (Esmaeilpour, 2015). Thus, behavior must be supported with positive attitude. Second dimension is the attitudinal loyalty, which underlines that behavior alone does not reflect brand loyalty (Tuominen, 1999). It impacts on conative loyalty that leads to consumers' intentions (Lewis \& Soureli, 2006) or commitment (Yang \& Peterson, 2004). Moreover, this two-dimensional measure of brand loyalty helps to determine the consumers' future behaviors in an accurate manner.

Brand trust is a psychological condition which occurs when one part has reliance over other part's reliability and integrity (Garbarino \& Johnson, 1999; Morgan \& Hunt, 1994). Brand trust is defined as the eagerness of the average consumer to believe in the capacity of the brand to perform its promised function (Chaudhuri \& Halbrook, 2001). In marketing literature, two-dimensional idea of brand trust is more commonly existed (Doney \& Cannon, 1997; Ganesan, 1994; Morgan \& Hunt, 1994). Reliability is the first dimension of the brand trust while having both technical and/or competence-based nature, it also involves the capability and eagerness to keep promises and satisfy consumers' needs. Intentions are the second dimension; composing the attribution of good intentions to brand about consumers' and well-beings' interests and welfare (Delgado-Ballester \& Munuera-Aleman, 2005; Huang, 2015).

Consumers develop trust after evaluating brand's offer (Kabadayi \& Alan, 2012). Therefore, consumers would like to have sustainable relationships with brands that offer safety, honesty, and reliability (Doney \& Cannon, 1997). Reliability, integrity, and intention form accumulated presumptions. Consumer's accumulated presumptions affect brand accumulated presumptions including reliability, integrity, and intention and reflect the brand trust as a psychological variable 
while affecting brand (Kimpakorn \& Tocquer, 2010). Brand trust is measured by the ability for the brand to deliver its promises. Trust can enhance or destroy a relationship between brand and customers (Keller, 2003). As customers buy a service before experiencing it, cultivation and management of trust is a key to build a relationship with customers (Kinard \& Capella, 2006).

The development and maintenance of brand trust via Internet becomes critically important, especially highly unpredictable markets with reduced product differentiation (Fournier \& Yao, 1997; Papadopoulou, Andreou, Kanellis, \& Martakos, 2001; Urban, Sultan, \& Qualls, 2000). Privacy, security, and experience are the preeminent issues in brand trust (Ha \& Perks, 2005). According to Krishnamurthy (2001), consumers who had positive security measure while using online shopping websites, tend to develop a strong brand trust. Privacy is another key factor that affects brand trust. According to Hoffman, Novak, and Peralca (1998), customers who are generally uninterested in online shopping, given up from doing online shopping not because of functionality, but because of privacy issues, especially protecting personal information. Ha and Perks (2005) mentioned that consumers tend to remember best the last experience (recency effect) meaning that one positive experience is effective in altering the perceptions of more than one preceding negative experience. According to Ganesan (1994), experience is the antecedent of brand trust.

\section{Logistics Service Quality Literature in Marketing}

Logistics used to be considered important for connecting production and consumption. According to this opinion, logistics is seen as a cost generator (Ballou, 2004). However, this opinion started to change in the mid-1990s with the idea of logistics delivers quality and generates customer satisfaction and loyalty (Richey, Daugherty, \& Roath 2007). Research done by Millen, Sohal, and Moss (1999) showed that customer satisfaction is the key benefit of LSQ. Researchers have dedicated themselves to service quality research (Abdullah, 2006). Origins of LSQ research are based on Perreault and Russ's $(1974,1976)$ studies. According to them, logistics activities create time, place and utility while creating product value. Moreover, Gilmour (1977) identified the importance of customer service in distribution and logistics activities. Later, Mentzer, Gomes, and Krapfel (1989) followed the Bienstock, Mentzer, and Bird's (1997) methodology to develop physical distribution service quality (PDSQ) and designated PDSQ indicators as accepted availability, timeliness, efficient delivery, price, product quality, and sales support and warranty. Emerson and Grimm (1996) improved Mentzer et al.'s (1989) framework and included communication as an additional logistics dimension. Innis and La Londe (1994) identified 32 features of service quality while investigating the impact of physical distribution performance on customer satisfaction, attitudes, and purchase intention. Mentzer, Flint, and Kent (1999) and Mentzer et al. (2001) tried to develop its LSQ concept; while Franceschini and Rafele (2000) identified eight indicators of LSQ and created those indicators consistent with SERVEQUAL. Leuschner, Lambert, and Knemeyer (2012) included place factor in the LSQ scale to compare the effect of logistics and marketing attributes.

In this study, Mentzer et al.'s (1999) LSQ theory is adopted which was empirically validated. Mentzer et al. (1999) extended the concept of service quality into logistics. In this model, nine interrelated features have been conceptualized. The nine features that are shown in Figure 2 are information quality, ordering procedures, order release quantities, timeliness, order accuracy, order quality, order condition, order discrepancy handling, and personnel contact quality (Mentzer et al., 1999). 


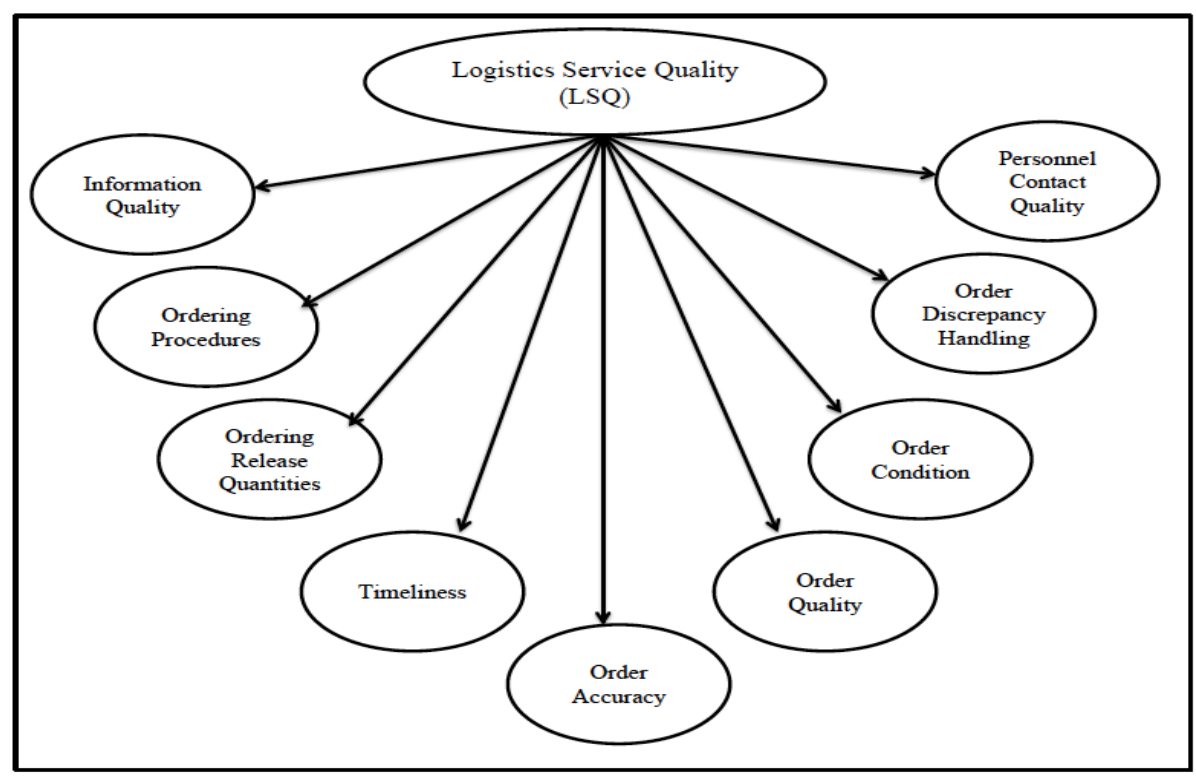

Figure 2. Logistics service quality

\section{Research Hypotheses}

In line with research conceptual model, the hypotheses were formulated as following:

$\mathbf{H}_{\mathbf{1}}$ : There is a relationship between Logistics Service Quality (LSQ) and Perceived Quality (PQ).

$\mathbf{H}_{1 \mathbf{a}}$ : There is a relationship between Order Accuracy (OA) and Perceived Quality (PQ).

H1b: There is a relationship between Personal Contact Quality (PCQ) and Perceived Quality (PQ).

$\mathbf{H}_{1 \mathbf{c}}$ : There is a relationship between Order Discrepancy Handling (ODH) and Perceived Quality (PQ).

$\mathbf{H}_{\mathbf{1 d}}$ : There is a relationship between Timelines (T) and Perceived Quality (PQ).

$\mathbf{H}_{1 \mathrm{e}}$ : There is a relationship between Ordering Procedure (OP) and Perceived Quality (PQ).

$\mathbf{H}_{1 \mathbf{f}}$ : There is a relationship between Order Condition (OC) and Perceived Quality (PQ).

$\mathbf{H}_{2}$ : There is a relationship between Logistics Service Quality (LSQ) and Brand Loyalty (BL).

$\mathbf{H}_{2 \mathbf{a}}$ : There is a relationship between Order Accuracy (OA) and Brand Loyalty (BL).

$\mathbf{H}_{\mathbf{2 b}}$ : There is a relationship between Personal Contact Quality (PCQ) and Brand Loyalty (BL).

$\mathbf{H}_{2 \mathbf{c}}$ : There is a relationship between Order Discrepancy Handling (ODH) and Brand Loyalty (BL).

$\mathbf{H}_{2 \mathbf{d}}$ : There is a relationship between Timelines (T) and Brand Loyalty (BL).

$\mathbf{H}_{2 \mathrm{e}}$ : There is a relationship between Ordering Procedure (OP) and Brand Loyalty (BL).

$\mathbf{H}_{\mathbf{2}}$ : There is a relationship between Order Condition (OC) and Brand Loyalty (BL).

$\mathbf{H}_{3}$ : There is a relationship between Logistics Service Quality (LSQ) and Brand Trust (BT).

$\mathbf{H}_{3 \mathbf{a}}$ : There is a relationship between Order Accuracy (OA) and Brand Trust (BT).

$\mathbf{H}_{3 \mathbf{b}}$ : There is a relationship between Personal Contact Quality (PCQ) and Brand Trust (BT).

$\mathbf{H}_{3 \mathbf{c}}$ : There is a relationship between Order Discrepancy Handling (ODH) and Brand Trust (BT).

$\mathbf{H}_{3 \mathbf{d}}$ : There is a relationship between Timelines (T) and Brand Trust (BT).

$\mathbf{H}_{3 \mathbf{e}}$ : There is a relationship between Ordering Procedure (OP) and Brand Trust (BT).

$\mathbf{H}_{3 \mathbf{f}}$ : There is a relationship between Order Condition (OC) and Brand Trust (BT). 


\section{Method}

We employed a survey method to measure the effect of perceived logistics service quality on perceived quality, brand loyalty, and brand trust in the context of e-commerce. Measurement items were drawn from existing scales as reported in the following section.

\section{Scale Development}

This study used measurement items for each construct from the relevant literature. The questionnaire included four parts. The first part recorded basic demographic information about respondents; while second part recorded respondents' e-commerce habits. The third and fourth parts recorded information about assessing logistics service quality, perceived quality, brand loyalty, and brand trust, respectively. All items except demographic information and e-commerce habits were measured on a 5-point Likerttype scale from "strongly disagree" (1) to "strongly agree" (5). The informants were asked to answer questions according to their perception of brand related factors. The third part measures LSQ with the help of ordering procedures, ordering release quantities, timeliness, order accuracy, order quality, order condition, order discrepancy handling, and personnel contact quality. The items for LSQ were adopted from that of Mentzer et al.'s (1999). The fourth part measures brand related factors. We adopted scales for perceived quality from Yoo et al. (2000) and Atilgan et al. (2005). For brand loyalty, we adopted scales from Yoo et al. (2000), Beatty and Kahle (1988), and Zeithaml, Berry, and Parasuraman (1996). Lastly, we adopted scales for brand trust from Kimpakom and Tocquer (2010), and Dogan and Ozkara (2013).

\section{Data Collection and Sample}

Web-based survey tool was used to gather perceptions of perceived logistics service quality and brand factors from customers. These tools help researchers to create and deliver surveys to participants/informers in an agreeable, expeditious manner. Moreover, web-based survey tools produce results simultaneously; so that researchers are able to see results as soon as survey is finished (Bunchanan \& Hvizdak, 2009). Target informants were consumers who buy especially clothing textile and/or books from online shopping websites. To assure accuracy in responses, consumers were asked to indicate their most common used online shopping websites and last used online shopping websites. Answers, which were not proper, eliminated during the data entry process.

We followed Salant and Dillman's (1994) recommended survey methodology for pretest survey. This process consisted of responding the following questions:

- Does each question measure exactly the desired-item?

- Do respondents understand each word?

- Do respondents understand each question in the same way?

- Are choices for each close-ended questions valid for all respondents?

- Is the survey purified from the undesired factors make respondents uncomfortable?

- Are answer choices enough for each question?

- Is there any factor in the survey that leads into respondents' bias or inducements?

Pretests are implemented by experts who are well informed about conducting survey by face-toface interviews (Altunisik, 2008; Iacobucci \& Churchill, 2010). Both researchers were with the experts during the pre-test stage.

Dillman's (2000) recommended survey methodology is followed for final survey. This process is based on taking three or more contacts from each respondent considering two waves of survey distribution (Davis, Golicic, \& Marquardt, 2009). The contact protocol included survey pre- 
notification, initial survey packets, follow-up postcard reminders of the survey due date, and second distribution of survey packets to non-respondents.

Convenience sampling method is implemented. Complete surveys were received from 196 consumers. Following this, 193 out of 196 were usable questionnaires. During data analysis process, SPSS 15.0 software package program was used. Demographic characteristics of respondents are provided in Table 1.

Table 1

Sample Demographic Characteristics

\begin{tabular}{|c|c|c|}
\hline & & Percent \\
\hline \multirow[t]{2}{*}{ Gender } & Female & 69.4 \\
\hline & Male & 30.6 \\
\hline \multirow[t]{4}{*}{ Age } & Less than 24 & 19.2 \\
\hline & $24-44$ & 64.2 \\
\hline & $45-64$ & 13.5 \\
\hline & More than 65 & 3.1 \\
\hline \multirow[t]{5}{*}{ Education } & Primary Education & 1.6 \\
\hline & High School & 3.1 \\
\hline & Associate School & 2.1 \\
\hline & University & 44.0 \\
\hline & Graduate School & 49.2 \\
\hline \multirow[t]{4}{*}{ Income Level } & Less than $1.000 \mathrm{TL}$ & 21.2 \\
\hline & $1.000-3.000 \mathrm{TL}$ & 35.2 \\
\hline & $3.001-5.000 \mathrm{TL}$ & 33.7 \\
\hline & More than $5.001 \mathrm{TL}$ & 9.8 \\
\hline \multirow[t]{4}{*}{ Online Shopping Numbers of Last Month } & Less than 5 & 83.9 \\
\hline & $6-10$ & 14.0 \\
\hline & $11-15$ & 1.6 \\
\hline & More than 16 & 0.5 \\
\hline \multirow[t]{4}{*}{ Online Shopping Website Numbers Used in Last Month } & $1-3$ & 86.0 \\
\hline & $4-6$ & 11.4 \\
\hline & $7-9$ & 0.5 \\
\hline & More than 10 & 2.1 \\
\hline
\end{tabular}

According to demographic characteristics, up to $24(19 \%)$ and $25-44$ age range (64\%) became main age groups; while most of the respondents are female (69\%).

\section{Results}

In order to ensure that key informants were appropriate for the surveys, all respondents were asked to report their most commonly used and most recently used online shopping website. Most commonly and most recently used online shopping websites are shown in Table 2.

Table 2

Online Shopping Websites that Most Commonly and Recently Used

\begin{tabular}{lcccc}
\hline & Frequency & Percent & Frequency & Percent \\
\hline Online Shopping Websites that Most & & Online Shopping Websites that & \\
\hline
\end{tabular}




\begin{tabular}{|c|c|c|c|c|c|}
\hline Commonly Used & & & Most Recently Used & & \\
\hline www.trendyol.com & 24 & 12.4 & www.hepsiburada.com & 25 & 13.0 \\
\hline www.hepsiburada.com & 21 & 10.9 & www.kitapyurdu.com & 18 & 9.3 \\
\hline www.kitapyurdu.com & 19 & 9.8 & www.trendyol.com & 17 & 8.8 \\
\hline www.idefix.com & 18 & 9.3 & www.morhipo.com & 14 & 7.3 \\
\hline www.dr.com & 15 & 7.8 & www.dr.com & 12 & 6.2 \\
\hline www.n11.com & 15 & 7.8 & www.idefix.com & 12 & 6.2 \\
\hline www.markafoni.com & 12 & 6.2 & www.n11.com & 11 & 5.7 \\
\hline www.gittigidiyor.com & 12 & 6.2 & www.markafoni.com & 10 & 5.2 \\
\hline www.morhipo.com & 10 & 5.2 & www.gittigidiyor.com & 7 & 3.6 \\
\hline www.aliexpress.com & 8 & 4.1 & www.aliexpress.com & 5 & 2.6 \\
\hline www.amazon.com & 6 & 3.1 & Others & 62 & 32.24 \\
\hline Others & 33 & 16.6 & Total & 193 & 100 \\
\hline Total & 193 & 100 & & & \\
\hline
\end{tabular}

Moreover, reason to prefer online shopping is asked from informants and the results are displayed in Table 3.

Table 3

Reasons to Prefer Online Shopping

\begin{tabular}{cc}
\hline & Percent \\
\hline Fair prices & 78.23 \\
Time saving & 74.00 \\
Convenience & 67.35 \\
Wide product range & 63.73 \\
Benchmarking opportunity & 49.22 \\
Free shipping option & 36.78 \\
Fast delivery & 29.01 \\
Payment options & 23.31 \\
Detailed product information & 17.61 \\
Safety services & 9.32 \\
After sale services & 3.62 \\
Customer support services & 3.62 \\
\hline
\end{tabular}

According to Table 3, the majority of informants prefer online shopping mostly because of fair prices options (78\%). Second reason to choose online shopping is having the chance of time saving (about 74 percent). However, customer support services (3.62\%) and after sale services $(3.62 \%)$ are the least important reasons.

\section{Data Analysis}

The analysis involved several procedures. Factor analysis was used to identify underlying LSQ themes. Correlation analysis was then used to show which hypotheses are supported and not.

\section{Empirical Analysis}

To measure the perceived relationship by online shopping users between Logistics Service Quality (Order Accuracy, Personal Contact Quality, Order Discrepancy Handling, Timelines, Ordering Procedure, Order Condition) and Brand Factors (Brand Loyalty, Perceived Brand Quality, Brand 
Trust), two scales were created that have respectively 17 and 9 variables. In order to make data reduction of the number of variables, factor analysis in SPSS 15.0 was performed in both scales. In that way obtained data will become more understood and interpreted.

\section{Factor Analysis and Reliability Analysis}

The reliability tests performed to determine the reliability and validity of the datum. Cronbach's Alpha value was measured as 0.91 for Logistics Service Quality variables and 0.83 for Brand factors. Since Cronbach's Alpha values are greater than 0.7, both variable groups were considered reliable.

SPSS 15.0 software is used to analyze the data. We examined the SPSS output for a Kaiser-MeyerOlkin (KMO) on 193 samples for LSQ. As a result, which are shown in Table 4, the KMO measure of 0.88 indicated a very high sampling adequacy and good preconditions for factor analyses. In addition, results of Bartlett's Test for Sphericity had significant differences $\left(x^{2}=19.39, d f=13\right)$. According to the above test results, the samples were suitable for factor analyses (Güriş \& Astar, 2014). Table 4 represents KMO and Bartlett's test of logistics service quality.

Table 4

KMO and Bartlett's Test of Logistics Service Quality

\begin{tabular}{cc}
\hline $\begin{array}{c}\text { Kaiser-Meyer-Olkin Measure of Sampling Adequacy } \\
\text { Bartlett's Test of Sphericity }\end{array}$ & 0.88 \\
Approx. Chi-Square & 19.39 \\
df & 13 \\
Sig. & 0.000 \\
\hline
\end{tabular}

We used PCA and varimax rotation in the paper. The Kaiser rule is to drop all components with eigenvalues under 1.0. It may overestimate or underestimate the perceived LSQ of customers. While performing PCA for 17 items, 6 factors proved rational in the scree plot which showed the sorted eigenvalues. The total cumulative variance is $79.46 \%$. The factor pattern that isolated the 6 factors showed that each factor loading was above 0.5 . Table 5 exhibits the factor analysis of logistics service quality variables.

Table 5

Factor Analysis of Logistics Service Quality Variables

\begin{tabular}{|c|c|c|c|c|c|c|c|c|}
\hline & & Variance & 1 & 2 & 3 & 4 & 5 & 6 \\
\hline L13 & & & .83 & & & & & \\
\hline L12 & Factor $1-(\mathrm{OA})$ & 19.54 & .80 & & & & & \\
\hline L14 & & & .78 & & & & & \\
\hline L5 & & & .64 & & & & & \\
\hline L8 & & & & .85 & & & & \\
\hline L7 & Factor $2-(\mathrm{PCQ})$ & 17.45 & & .82 & & & & \\
\hline L6 & & & & .75 & & & & \\
\hline L9 & & & & .68 & & & & \\
\hline L15 & Factor 3-(ODH) & 15.62 & & & .87 & & & \\
\hline L16 & & & & & .86 & & & \\
\hline L17 & & & & & .79 & & & \\
\hline L1 & Factor $4-(\mathrm{T})$ & 10.22 & & & & .84 & & \\
\hline L2 & & & & & & .82 & & \\
\hline L10 & Factor $5-(\mathrm{OP})$ & 8.55 & & & & & .80 & \\
\hline
\end{tabular}


Factor 1 refers to whether deliveries include any wrong items or always delivered on promised amount, which is named "Order Accuracy (OA)". There are four variables under this factor. The highest factor loading is that "Shipments rarely contains the wrong items" (0.83). While examining variables of factor loadings, variables are found to be associated with order accuracy and order quality. The variance value of this factor was $19.54 \%$.

Factor 2 is named Personnel Contact Quality (PCQ) meaning that customer direction to the supplier's logistics contact people. It measures whether the customer service personnel are informed, aware of the responsibilities, and are able to help in finding solutions to problems. There are four variables under this factor. The highest factor loading is, "Problems are resolved by the designated DLA contact person" (0.85). While examining variables factor loadings, variables are found to be associated with Personal Contact Quality. The variance value of this factor was $17.45 \%$.

Factor 3 is named as "Order Discrepancy Handling (OHD)" which refers to how logistics companies are able to handle with the discrepancy situations which occurs in orders after the arrival. If customers receive orders that are not accurate and are in poor condition, or are of poor quality, they will seek corrections from the logistics company. There are three variables under this factor. The highest factor loading is "Correction of delivered quality discrepancies (report of discrepancy is satisfactory" (0.87). While examining variables factor loadings, variables are found to be associated with Order Discrepancy Handling. The variance value of this factor was 15.62.

Factor 4 is named "Timeliness (T)" which refers to whether orders arrive at the customer location when promised. Also, timeliness refers to the length of time between order placement and receipt. There are two variables under this factor. The highest factor loading is "Deliveries arrive on the date promised" (0.84). While examining variables factor loadings, variables are found to be associated with Timelines. The variance value of this factor was $10.22 \%$.

Factor 5 refers to how well logistics companies ordering procedure is. Specifically, customers' ideas about whether the process is effective and/or easy to use, which is named "Order Procedure (OP)". There are two variables under this factor. The highest factor loading is "Requisition procedures are easy to use" $(0.80)$. While examining variables factor loadings, variables are found to be associated with Ordering Procedure. The variance value of this factor was $8.55 \%$.

Factor 6 is named "Order Condition (OC)" which refers to the loading and unloading procedure that products do not get damaged and orders are scientifically sorted. There are two variables under this factor. The highest factor loading is "Offers tracking and tracing information service" $(0.77)$. While examining variables factor loadings, variables are found to be associated with Order Condition. The variance value of this factor was $8.06 \%$.

We examined the SPSS output for a Kaiser-Meyer-Olkin (KMO) on 193 samples for brand factors. As a result, the KMO measure of 0.88 indicated a very high sampling adequacy and good preconditions for factor analyses. In addition, results of Bartlett's Test for Sphericity had significant differences $\left(x^{2}=62.53, d f=36\right)$ and approximate Chi-Square was regarded to be 62.53 . According to the above test results, the samples were suitable for factor analyses (Güriş \& Astar, 2014).

We used PCA and varimax rotation in the paper. The Kaiser rule is to drop all components with eigenvalues under 1.0. It may overestimate or underestimate the perceived LSQ of customers. While performing PCA for 9 items, 3 factors proved rational in the scree plot, which showed the sorted 
eigenvalues. The total cumulative variance is $66.95 \%$. The factor pattern that isolated the 3 factors showed that each factor loading was above 0.5 . Table 6 shows the factor analysis of brand factors.

Table 6

Factor Analysis of Brand Factors

\begin{tabular}{lcccc}
\hline & Variance & 1 & 2 \\
\hline B7 & Factor 1-(PQ) & & .77 & \\
B5 & & 25.23 & .71 & \\
B4 & & .68 & .77 \\
B1 & Factor 2-(BL) & & & .69 \\
B2 & & 22.86 & .69 & .84 \\
B3 & & & & .66 \\
B9 & Factor 3-(BT) & 18.85 & & .52 \\
B8 & & & & \\
B6 & Total & 66.95 & & \\
\hline
\end{tabular}

Factor 1 is named "Perceived Quality (PQ)" which refers to online shopping websites products quality. There are three variables under this factor. The highest factor loading is "I never had a bad experience with this brand" (0.77). While examining variables factor loadings, variables are found to be associated with Perceived Quality. The variance value of this factor was $25.23 \%$.

Factor 2 refers to how online shopping website satisfies customers' needs; how hard it is to change online shopping websites and whether the informants will use the same website again, which is named "Brand Loyalty (BL)." There are three variables under this factor. The highest factor loading is "Changing brands would require too much energy of me" $(0.77)$. While examining variables factor loadings, variables are found to be associated with Brand Loyalty. The variance value of this factor was $22.86 \%$.

Factor 3 is named "Brand Trust (BT)" which refers to how reliable is the online shopping websites' trustworthiness. There are three variables under this factor. The highest factor loading is "website ensures my credit card information" (0.84). While examining variables factor loadings, variables are found to be associated with Brand Trust. The variance value of this factor was $18.85 \%$.

In the literature review part, the conceptual model of the study was explained. However, according to factor analysis, rearranging the conceptual model becomes requisite because the Information Quality indicator falls under the Perceived Quality indicator. So, rearranged conceptual model are shown in Figure 3. 


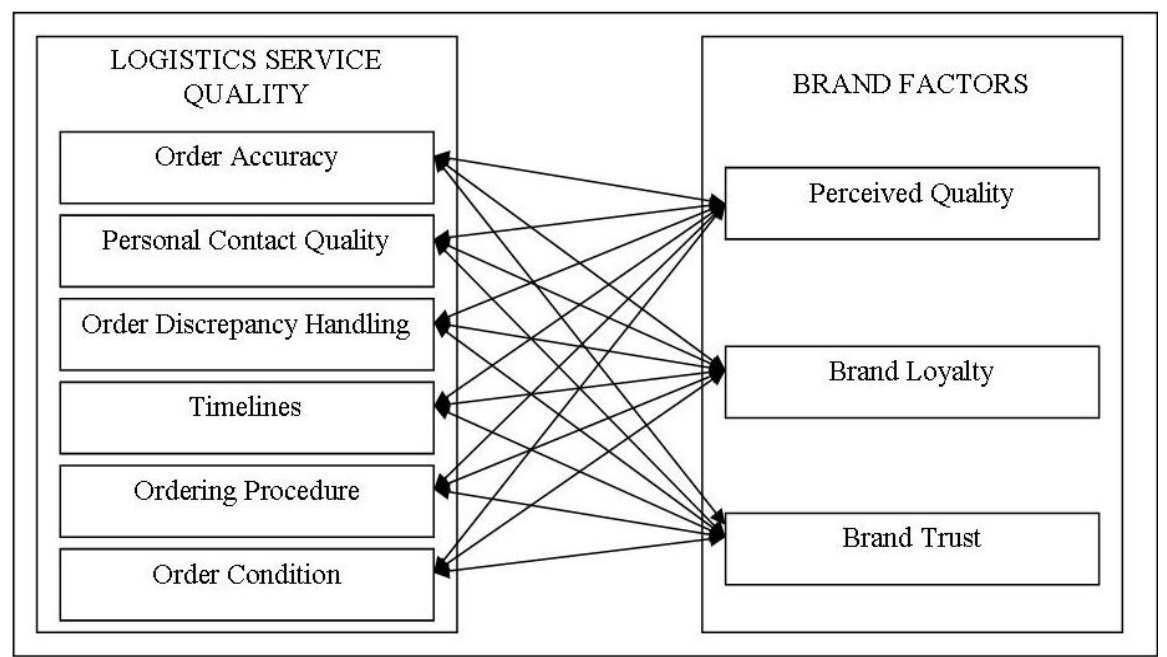

Figure 3. Rearranged conceptual model

\section{Correlation Analysis Results (Hypotheses Testing)}

Correlations measure how variables are related. When bivariate correlations obtained from SPSS, one can select two-tailed or one-tailed probabilities. If the direction of association is known in advance, one-tailed option must be selected; otherwise, two-tailed option will be suitable. Correlation coefficients significant at the 0.05 level is classified with a one-tailed option while significant level is 0.01 are classified with two-tailed option (Bryman \& Cramer, 2002). The correlations degrees are shown in Table 7 (Çağlar, 2014).

Table 7

Relations Degree of Correlation Coefficient

\begin{tabular}{cc}
\hline Correlation Coefficient & Relation Degree \\
\hline $01-10$ & No Relation \\
$11-20$ & Very Weak Relation \\
$21-30$ & Relatively Very Weak Relation \\
$31-40$ & Weak Relation \\
$41-50$ & Relatively Weak Relation \\
$51-60$ & Slightly Weak Relation \\
$61-70$ & Slightly Strong Relation \\
$71-80$ & Relatively Strong Relation \\
$81-90$ & Strong Relation \\
$91-100$ & Relatively Very Strong Relation \\
& Very Strong Relation \\
\hline
\end{tabular}

Strength and direction of a relationship between two variables are measured by correlation coefficient. The value of $r$ ranges between -1 and +1 (Pearson, 2013). A correlation, which is greater than $0.8(80)$, is mostly described as strong, while a correlation, which is less than 0.5 , is generally described as weak (Pino, Tzemis, Ioannou, \& Kouroupetroglou, 2013)

Table 8 presents the results of $\mathrm{H}_{1}$ and 6 Sub-hypotheses. 
Table 8

Results of $H_{l}$ and 6 Sub-Hypotheses

\begin{tabular}{|c|c|c|c|c|}
\hline & & Pearson Correlation & Sig. (2-tailed) & Result \\
\hline $\mathrm{H}_{1 \mathrm{a}}$ & $\begin{array}{l}\text { There is a relationship } \\
\text { between } \mathrm{OA} \text { and } \mathrm{PQ} \text {. }\end{array}$ & $0.29 * *$ & 0.000 & Accepted \\
\hline $\mathrm{H}_{1 \mathrm{~b}}$ & $\begin{array}{l}\text { There is a relationship } \\
\text { between PCQ and PQ. }\end{array}$ & $0.29 * *$ & 0.000 & Accepted \\
\hline $\mathrm{H}_{1 \mathrm{c}}$ & $\begin{array}{l}\text { There is a relationship } \\
\text { between ODH and PQ. }\end{array}$ & $0.33 * *$ & 0.000 & Accepted \\
\hline $\mathrm{H}_{1 \mathrm{~d}}$ & $\begin{array}{l}\text { There is a relationship } \\
\text { between } \mathrm{T} \text { and } \mathrm{PQ} \text {. }\end{array}$ & $0.36^{* *}$ & 0.000 & Accepted \\
\hline $\mathrm{H}_{1 \mathrm{e}}$ & $\begin{array}{l}\text { There is a relationship } \\
\text { between } \mathrm{OP} \text { and } \mathrm{PQ} \text {. }\end{array}$ & $0.23 * *$ & 0.001 & Accepted \\
\hline $\mathrm{H}_{1 \mathrm{f}}$ & $\begin{array}{l}\text { There is a relationship } \\
\text { between } \mathrm{OC} \text { and } \mathrm{PQ} \text {. }\end{array}$ & 0.10 & 0.14 & Rejected \\
\hline
\end{tabular}

** Correlation is significant at the 0.01 level

Table 9 shows the results of $\mathrm{H}_{2}$ and sub-hypotheses.

Table 9

Results of $\mathrm{H}_{2}$ and Sub-Hypotheses

\begin{tabular}{llccc}
\hline & & Pearson Correlation & Sig. (2-tailed) & Result \\
\hline $\mathrm{H}_{2 \mathrm{a}}$ & There is a relationship between OA and BL. & 0.13 & 0.06 & Rejected \\
$\mathrm{H}_{2 \mathrm{~b}} \quad$ There is a relationship between PCQ and BL. & $0.16^{*}$ & 0.02 & Accepted \\
$\mathrm{H}_{2 \mathrm{c}} \quad$ There is a relationship between ODH and BL. & -0.33 & 0.64 & Rejected \\
$\mathrm{H}_{2 \mathrm{~d}} \quad$ There is a relationship between T and BL. & 0.13 & 0.06 & Rejected \\
$\mathrm{H}_{2 \mathrm{e}} \quad$ There is a relationship between OP and BL. & 0.07 & 0.33 & Rejected \\
$\mathrm{H}_{2 \mathrm{f}}$ & There is a relationship between OC and BL. & 0.13 & 0.06 & Rejected \\
\hline
\end{tabular}

*Correlation is significant at the 0.05 level (2-tailed).

Table 10 exhibits the results of $\mathrm{H}_{3}$ and sub-hypotheses.

Table 10

Results of H3 and Sub-Hypotheses

\begin{tabular}{|c|c|c|c|c|}
\hline & & Pearson Correlation & Sig. (2-tailed) & Result \\
\hline H3a & There is a relationship between $\mathrm{OA}$ and $\mathrm{BL}$. & 0.13 & 0.000 & Accepted \\
\hline H3b & There is a relationship between PCQ and BL. & $0.16^{*}$ & 0.000 & Accepted \\
\hline H3c & There is a relationship between ODH and BL. & -0.33 & 0.000 & Accepted \\
\hline H3d & There is a relationship between $\mathrm{T}$ and $\mathrm{BL}$. & 0.13 & 0.000 & Accepted \\
\hline H3e & There is a relationship between OP and BL. & 0.07 & 0.000 & Accepted \\
\hline H3f & There is a relationship between $\mathrm{OA}$ and $\mathrm{BL}$. & 0.13 & 0.001 & Accepted \\
\hline
\end{tabular}

**Correlation is significant at the 0.01 level. 


\section{Discussion}

The current research tested the relationships between 6 LSQ features including order accuracy, personal contact quality, order discrepancy handling, timeliness, ordering procedure and order condition and brand factors, namely perceived quality, brand trust, and brand loyalty.

The present paper makes contributions to the marketing literature in several ways. First of all, the research is based on development and measurement of a logistics service quality framework considering the e-commerce perspective. Second, the results for $\mathrm{H}_{1 \mathrm{a}}, \mathrm{H}_{1 \mathrm{~b}}, \mathrm{H}_{1 \mathrm{c}}, \mathrm{H}_{1 \mathrm{~d}}$, and $\mathrm{H}_{1 \mathrm{e}}$ show that logistics service quality contributes to perceived quality with logistics service. However, the rejection of $\mathrm{H}_{2 \mathrm{a}}, \mathrm{H}_{2 \mathrm{c}}, \mathrm{H}_{2 \mathrm{~d}}, \mathrm{H}_{2 \mathrm{e}}$, and $\mathrm{H}_{2 \mathrm{f}}$ shows that logistics service quality does not affect brand loyalty of an online shopping websites. The results for $\mathrm{H}_{3 \mathrm{a}}, \mathrm{H}_{3 \mathrm{~b}}, \mathrm{H}_{3 \mathrm{c}}, \mathrm{H}_{3 \mathrm{~d}}, \mathrm{H}_{3 \mathrm{e}}$, and $\mathrm{H}_{3 \mathrm{f}}$ show that logistics service quality contributes to brand trust of an online shopping websites.

However, as an unexpected finding of this research, the rejection of $\mathrm{H}_{1 \mathrm{f}}$ shows that there was no relationship between order conditions and perceived quality. Moreover, from the acceptance of $\mathrm{H}_{2 \mathrm{~b}}$, it is seen that there is a relationship between personal contact quality and brand trust. Reason for this could be when logistics service related issues and/or complaints are solved efficiently through high quality services; consumer's brand trust will affect positively.

To sum up, this research reveals the importance of logistics service and the quality of these in the context of e-commerce industry and measures the proposed framework of logistics service quality with three brand factors. Furthermore, it provides logistics managers with empirical evidence of the importance of service quality and brand factors during competition. According to this perspective, managers should consider logistics service since the results of this research showed that logistics service quality contributes to perceived quality and brand trust of the online shopping website. Additionally, the results approved the importance of logistics services for the success of online shopping websites especially companies that outsource logistics activities.

\section{Conclusion}

This paper proposed a conceptual framework of logistics service quality effect on brand factors in the context of e-commerce and tested several hypotheses using the collected data. The paper verified the effect of logistics service quality on brand factors of online shopping websites. However, there are several limitations to the paper that could be considered as future research directions. One of the limitations of the research is that the survey was only conducted in Turkey; future data could be collected in other countries so as to verify whether different cultural backgrounds impact the research results. Second, a majority of respondents in this research were female $(69 \%)$; therefore, future research could consider gender as a control variable to analyze whether gender influences the research results. Third, the measurement scales for LSQ and brand factors were both derived from extant literature. New measurement scales may be developed in future research to reflect any new trends and/or cultural differences. Moreover, future research can focus on comparing the performance differences between online shopping websites that are outsourcing and self-managing logistics services.

\section{References}

Aaker, D. A. (1991). Managing brand equity: Capitalizing on the value of a brand name. New York: The Free Press.

Abdullah, F. (2006). Measuring service quality in higher education: HEdPERF versus SERVPERF. Marketing Intelligence \& Planning, 24(1), 31-47.

Altunisik, R. (2008). Anketlerde veri kalitesinin iyileştirilmesi için ontest (Pilot Test) Yöntemleri. Pazarlama ve Pazarlama Araştırmaları Dergisi, 2, 1-17. 
Atilgan, E., Aksoy, S., \& Akinci, S. (2005). Determinants of the brand equity: A verification approach in the beverage industry in Turkey. Marketing Intelligence \& Planning, 23, 237-248.

Ballou, R. H. (2004). Business logistics/supply chain management: Planning, organizing, and controlling the supply chain. Upper Saddle River, New Jersey: Pearson Prentice Hall.

Beatty, S. E., \& Kahle, L. R. (1988). Alternative hierarchies of the attitude-behavioral relationship: The impact of brand commitment and habit. Journal of the Academy of Marketing Science, 16(2), 1-10.

Bienstock, C. C., Mentzer, J. T., \& Bird, M. M. (1997). Measuring physical distribution service quality. Journal of the Academy of Marketing Science, 25(1), 31-44.

Bryman, A., \& Cramer, D. (2002). Quantitative data analysis with SPSS release 10 for windows. Philadelphia, Routledge: Taylor and Francis Group.

Bunchanan, E. A., \& Hvizdak, E. E. (2009). Online survey tools: Ethical and methodological concerns of human research ethics committees. Journal of Empirical Research on Human Research Ethics, 4(2), 37-48.

Çağlar, B. (2014). E-Ticaret sektöründe algılanan lojistik hizmet performansı ile marka sadakati ve marka güveni arasındaki ilişki: Meslek yüksekokulu oğrencileri uzerinde bir araştırma. Online Academic Journal of Information Technology, 5(15), $75-88$.

Chaudhuri, A., \& Holbrook, M. B. (2001). The chain of effects from brand trust and brand affects to brand performance: The role of brand loyalty. Journal of Marketing, 65(2), 81-93.

Iacobucci, D., \& Churchill, G. A. (2010). Marketing research: Methodological foundations $\left(10^{\text {th }}\right.$ ed.). Mason, Ohio: SouthWestern Cengage Learning.

Davis, D. F., Golicic, S. L., \& Marquardt, A. (2009). Measuring Brand Equity for Logistics Services. The International Journal of Logistics Management, 20(2), 201-212.

Delgado-Ballester, E., \& Munuera-Aleman, J. L. (2005). Does brand trust matter to brand equity? Journal of Product and Brand Management, 14(3), 187-196.

Dillman, D. (2000). Mail and internet surveys: The tailored design method. New York: John Wiley \& Sons, Inc.

Dogan, V., \& Ozkara, B. Y. (2013). The role of online brand trust on the image of online brands. Journal of Internet Applications and Management, 4(2), 5-20.

Doney, P. M., \& Cannon, J. P. (1997). An examination of the nature of trust in buyer-seller relationships. Journal of Marketing, 61(2), 35-51.

Emerson, C. J., \& Grimm, C. M. (1996). Logistics and marketing components of customer service: An empirical test of the Mentzer, Gomes and Krapfel model. International Journal of Physical Distribution \& Logistics Management, 26(8), 2942 .

Esmaeilpour, F. (2015). The role of functional and symbolic brand associations on brand loyalty: A study on luxury brands. Journal of Fashion Marketing \& Management: An International Journal, 19(4), 467-484.

Franceschini, F., \& Rafele, C. (2000). Quality evaluation in logistics services. International Journal of Agile Management Systems, 2(1), 49-54.

Fournier, S., \& Yao, J. (1997). Reviving brand loyalty: A reconceptualization within the framework of consumer-brand relationships. International Journal of Research in Marketing, 14(5), 451-472.

Ganesan, S. (1994). Determinants of long-term orientation in buyer-seller relationships. Journal of Marketing, 58(2), 1-19.

Garbarino, E., \& Johnson, M. S. (1999). The different roles of satisfaction, trust and commitment in customer relationships. Journal of Marketing, 63(2), 70-87.

Gilmour, P. (1977). Customer service: Differentiating by market segment. International Journal of Physical Distribution, 7(3), 141-148.

Güriş S., \& Astar, M. (2014). Bilimsel araştırmalarda SPSS ile istatistik. Istanbul: DER Yayınerı.

Ha, H. Y. \& Perks, H. (2005). Effects of consumer perceptions of brand experience on the Web: Brand familiarity, satisfaction, and brand trust. Journal of Consumer Behavior, 4(6), 438-452.

Hoffman, D. L., Novak, T. P., \& Peralca, M. A. (1998). Building consumer trust in online environment: The case for information privacy. Communications of the ACM, 42(4), 80-85.

Huang, Y. K., Kuo, Y. W., \& Xu, S. W. (2009). Applying importance- performance analysis to evaluate logistics service quality for online shopping among retailing delivery. International Journal of Electronic Business Management, 7(2), $128-136$.

Huang, L. (2015). Quality or responsibility? The impact of two categories of corporate social responsibility on the consumerbrand relationship. Marketing Management Journal, 25(1), 27-41. 
Innis, D. E., \& La Londe, B. J. (1994). Customer service: The key to customer satisfaction, customer loyalty and market share. Journal of Business Logistics, 15(1), 1-28.

Jaafar, H. S., \& Rafiq, M. (2005). Customers' perceptions of service quality by TPL service providers in the United Kingdom: A confirmatory factor analysis. In H. Kotzab, S. Seuring, M. Muller, \& G. Reiner (Eds.), Research methodologies in supply chain management (pp.187-202). New York, NY: Physica-Verlag.

Jacoby, J., \& Kyner, D. B. (1973). Brand loyalty vs. repeat purchasing behavior. Journal of Marketing Research, 10(1), 1-9.

Kabadayi, E. T., \& Alan, A. K. (2012). Brand trust and brand affect: Their strategic importance on brand loyalty. Journal of Global Strategic Management, 11, 81-89.

Keller, K. L. (2003). Strategic brand management: Building, measuring and managing brand equity. Upper Saddle River, NJ: Prentice- Hall.

Kim, W. G., Jin-Sun, B., \& Kim, H. J. (2008). Multidimensional customer-based brand equity and its consequences in midpriced hotels. Journal of Hospitality \& Tourism Research, 32(2), 235-254.

Kimpakorn, N., \& Tocquer, G. (2010). Service brand equity and employee brand commitment. Journal of Services Marketing, 24(5), 378-388.

Kinard, B. R., \& Capella, M. L. (2006). Relationship marketing: The influence of consumer involvement on perceived service benefits. Journal of Service Marketing, 20(6), 359-368.

Krishnamurthy, S. (2001). A comprehensive analysis of permission marketing. Journal of Computer-Mediated Communication, 6(2), 4-6.

Lee, T. W. (1999). Using qualitative methods in organizational research. Thousand Oaks, CA: Sage Publications.

Leuschner, R., Lambert, D. M., \& Knemeyer, A. M. (2012). Logistics performance, customer satisfaction and share of business: A comparison of primary and secondary suppliers. Journal of Business Logistics, 33(3), 210-226.

Lewis, B. R., \& Soureli, M. (2006). The antecedents of consumer loyalty in retail banking. Journal of Consumer Behavior, $5(1), 15-31$.

Lin, Y., Luo, J., Cai, S., Ma, S., \& Rong, K. (2016). Exploring the service quality in the e-commerce context: A triadic view. Industrial Management and Data Systems, 116(3), 388-415.

Mentzer, J. T., Gomes, R., \& Krapfel, R. E. Jr. (1989). Physical distribution service: A fundamental marketing concept? Journal of the Academy of Marketing Science, 17(1), 53-62.

Mentzer, J. T., Flint, D. J., \& Kent, J. L. (1999). Developing a logistics service quality scale. Journal of Business Logistics, 20, 9-32.

Mentzer, J. T., Flint, D. J., \& Hult, T. M. (2001). Logistics service quality as a segment-customized process. Journal of Marketing, 65(4), 82-104.

Mentzer, T. M., \& Williams, L. R. (2001). The role of logistics leverage in marketing strategy. Journal of Marketing Channels, 8(3), 29-47.

Millen, R., Sohal, A., \& Moss, S. (1999). Quality management in the logistics function: An empirical study. The International Journal of Quality \& Reliability Management, 16(2), 166-180.

Morgan, R. M., \& Hunt, S. D. (1994). The commitment-trust theory of relationship marketing. Journal of Marketing, 58(3), $20-38$.

Papadopoulou, P., Andreou, A., Kanellis, P., \& Martakos, D. (2001). Trust and relationship building in electronic commerce. Internet Research: Electronic Networking Applications and Policy, 11(4), 322-332.

Park, H., \& Baek, S. (2007). Measuring service quality of online bookstores with Web Quall. In J. A. Jack (Eds.), Humancomputer interaction HCI applications and services (pp. 95-103). Heidelberg: Springer.

Perreault, W. D., \& Russ, F. A. (1974). Physical distribution service: A neglected aspect of marketing management. MSU Business Topics, 22(3), 37-45.

Perreault, W. D., \& Russ, F. A. (1976). Physical distribution service in industrial purchase decisions. Journal of Marketing, $40(2), 3-10$.

Pino, A., Tzemis, E., Ioannou, N., \& Kouroupetroglou, G. (2013). Using kinetic for ${ }^{`} \mathrm{~d}$ and ${ }^{\wedge} \mathrm{d}$ pointing tasks: Performance evaluation. In Editor M. Kurosu (Eds.), Human-computer interaction interaction modalities and techniques (pp. 358-368). Las Vegas: Springer.

Richey, R. G., Daugherty, P. J., \& Roath, A. (2007). Firm technological readiness and complementarity: Capabilities impacting logistics service competency and performance. Journal of Business Logistics, 28(1), 195-228.

Rohm, A. J., \& Swaminathan, V. (2004). A typology of online shoppers based on shopping motivations. Journal of Business Research, 57(7), 748-757. 
Salant, P., \& Dillman, D. (1994). How to conduct your own survey? New York: John Wiley and Sons, Inc.

Tuominen, P. (1999). Managing brand equity. LTA, 1(99), 65-100.

Urban, G. L., Sultan, F., \& Qualls, W. J. (2000). Placing trust at the center of your Internet strategy. Sloan Management Review, 42(1), 39-48.

Yang, Z., \& Peterson, R. T. (2004). Customer perceived value, satisfaction and loyalty: The role of switching costs. Psychology \& Marketing, 21(10), 799-822.

Yoo, B., Donthu, N., \& Lee, S. (2000). An examination of selected marketing mix elements and brand equity. Journal of the Academy of Marketing Science, 28, 195-211.

Wood, L. M. (2004). Dimensions of brand purchasing behavior: Consumers in the 18-24 age group. Journal of Consumer Behavior, 4(1), 9-24.

Zeithaml, V. A. (1998). Consumer perceptions of price, quality, and value: A means-end model and synthesis of evidence. Journal of Marketing, 52(3), 2-22.

Zeithaml, V. A., Berry, L. L., \& Parasuraman, A. (1996). The behavioral consequences of service quality. Journal of Marketing, 60(2), 31-46. 